\title{
EFFECT OF METHYL TESTOSTERONE ON URINARY 17-KETOSTEROIDS OF ADRENAL ORIGIN ${ }^{1,2,3}$
}

\author{
By E. C. REIFENSTEIN, JR., A. P. FORBES, F. ALBRIGHT, E. DONALDSON, \\ AND E. CARROLL \\ (From the Medical Service of the Massachusetts General Hospital and from the Department of \\ Medicine of the Harvard Medical School, Boston)
}

(Received for publication July 15,1944 )

Urinary 17-ketosteroids or their precursors are thought to arise from the adrenal cortices and the testes (1). Testosterone propionate is partially excreted as a 17-ketosteroid (2); on the other hand, 17-methyl testosterone is not excreted as such ( 3 to 5$)$. It follows that methyl testosterone in contradistinction to testosterone propionate, may be used to study the effect of a testosterone compound on the endogenous production of urinary 17-ketosteroids. The present paper is primarily concerned with the effect of methyl testosterone on the urinary 17 -ketosteroids of adrenal origin.

It is essential that such studies be carried out on individuals without functioning testicular tissue, since it is highly probable from animal experiments that testosterone inhibits its own endogenous production in the testis (6 to 8 ). It is difficult to obtain direct data in humans on the effect of testosterone on the urinary 17-ketosteroids of testicular origin. Thus, whereas the administration of methyl testosterone to a male without disease of the adrenals and testes induced a lowered 17-ketosteroid excretion (Figure 1), the entire effect may have been mediated through

1 The expenses of this investigation were defrayed in part by the Josiah Macy, Jr. Foundation and by a grant from the Committee on Endocrinology of the National Research Council. The work described in this paper was done under a contract, recommended by the Committee on Medical Research, between the Office of Scientific Research and Development and the Massachusetts General Hospital.

2 The authors wish to thank the Schering Corporation, Bloomfield, New Jersey, for the generous supplies of methyl testosterone (Oreton-M) and the Ayerst, McKenna and Harrison Company, New York, for the large amounts of chorionic gonadotropin (A.P.L.) used in these studies.

8 Read by title at the 36th annual meeting of the American Society for Clinical Investigation, May 8, 1944. the adrenal cortex. Actually to establish the point it would be necessary to give methyl testosterone to a male patient with Addison's disease. This was done (Figures 2 and 3 ), with suggestive but not conclusive results. Such an experiment runs into difficulties because the low initial level of 17-ketosteroid excretion makes the errors introduced by chromogens and other technical errors relatively more significant.

\section{CLINICAL CASES}

The influence of methyl testosterone on 17-ketosteroid excretion by individuals without testicular tissue was studied in 4 females with adrenal hyperplasia, 2 normal females, and 1 male with absence of functioning testicular tissue. Of the 4 patients with hyperplasia, 2 had Cushing's syndrome, and 2 , the adrenogenital syndrome. Whereas hyperplasia of the adrenal cortices may occur in both of these conditions, it is the authors' belief that in the first of them there is primarily an over-production of a hormone concerned with carbohydrate metabolism (the so-called "sugar" or " $\mathrm{S}$ " hormone), while in the second there is an over-production of a hormone concerned with anabolism of protoplasm, and masculinization (the so-called "nitrogen" or " $N$ " hormone) (9). In Cushing's syndrome there may be a compensatory over-production of " $\mathrm{N}$ " hormone as well (9). One "normal" female had no disease; the other had Paget's disease but was normal with respect to adrenal cortical function. The male patient had clinical evidence of hypoleydigism, a high excretion of follicle-stimulating hormone in the urine, a high 17-ketosteroid excretion, and, as demonstrated at exploration at the age of 8 , bilateral rudimentary testes. Thus, the evidence for lack of testicular tissue includes not only the clinical evidence of hypoleydigism and the findings at operation but the high titer of follicle-stimulating hormone (11). The high 17-ketosteroid excretion in spite of the clinical picture of hypoleydigism presumably represents compensatory hyperplasia of the adrenal cortex, such as is known to occur in animals castrated at birth $(12,13)$. The findings are entirely dissimilar to those in the usual eunuchoid patient, where the follicle-stimulating hormone excretion in the urine is usually normal or low and the 17 -ketosteroid is regularly low (14). 


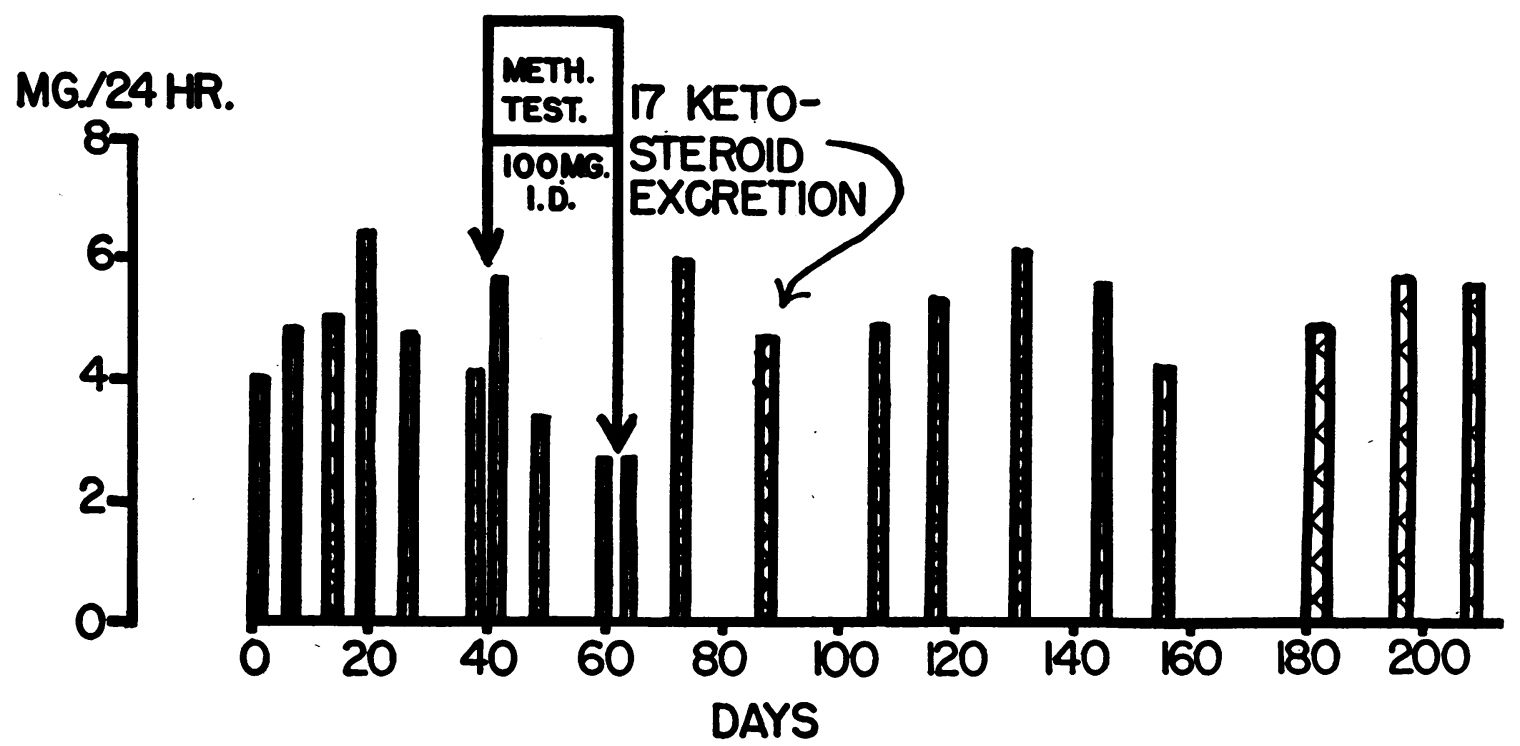

Fig. 1. Effect of Methyl Testosterone Therapy on the Urinary 17-Ketosteroid Excretion in a Man with Paget's Disease of Bone (Osteitis Deformans)

In this patient (B. F., No. 36002 , a male of 49 years), it is assumed that the functions of the adrenal cortices and testes are comparatively normal; however, the 17-ketosteroid excretion at the time of the experiment was low, probably because of debility (9). It will be noted that, although the control values were low (a mean of $4.8 \mathrm{mgm}$. per $24 \mathrm{hrs}$.) compared with the normal level in males (circa $14 \mathrm{mgm}$. per $24 \mathrm{hrs}$. (1)), with methyl testosterone therapy there was an orderly fall to a still lower level (a mean of $3.0 \mathrm{mgm}$. per $24 \mathrm{hrs}$.), and that with omission of the therapy the values rose to a level (a mean of $5.3 \mathrm{mgm}$. per $24 \mathrm{hrs}$.) approximating the pre-treatment level. The values for the first 6 days following a change in therapy were omitted in compiling the mean values. Note that the measurements were made on 24 -hour collections.

MG. /24HR.
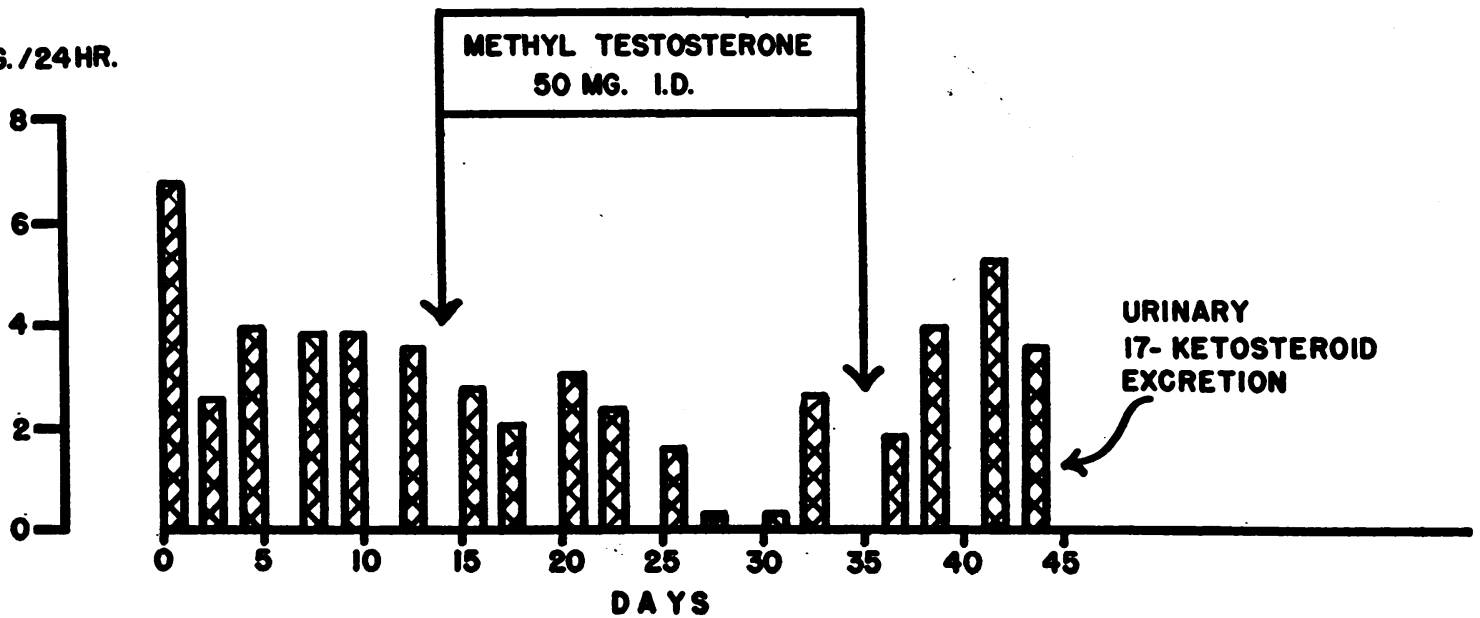

Fig. 2. Effect of Methyl Testosterone on the Urinary 17-Ketosteroid Excretion in a Man with Addison's DISEASE

This patient, K. P., No. 369416, a male of 44 years, had tuberculosis of the adrenals. At the time of the experiment, the patient was taking no medication except 3 grams of sodium chloride by mouth daily. It will be noted that during the control period the 17-ketosteroid excretion was low (a mean of $4.0 \mathrm{mgm}$. per $24 \mathrm{hrs}$.) compared with the normal level in males (circa $14 \mathrm{mgm}$. per $24 \mathrm{hrs}$. (1)); that under methyl testosterone therapy the level was suggestively lower (a mean of $1.6 \mathrm{mgm}$. per $24 \mathrm{hrs}$ ) ; that, when the drug was omitted, the level was increased (a mean of $4.3 \mathrm{mgm}$. per $24 \mathrm{hrs}$.). The values for the first 6 days following a change in therapy were omitted in compiling the mean values. Note that the measurements were made on 24-hour collections. 


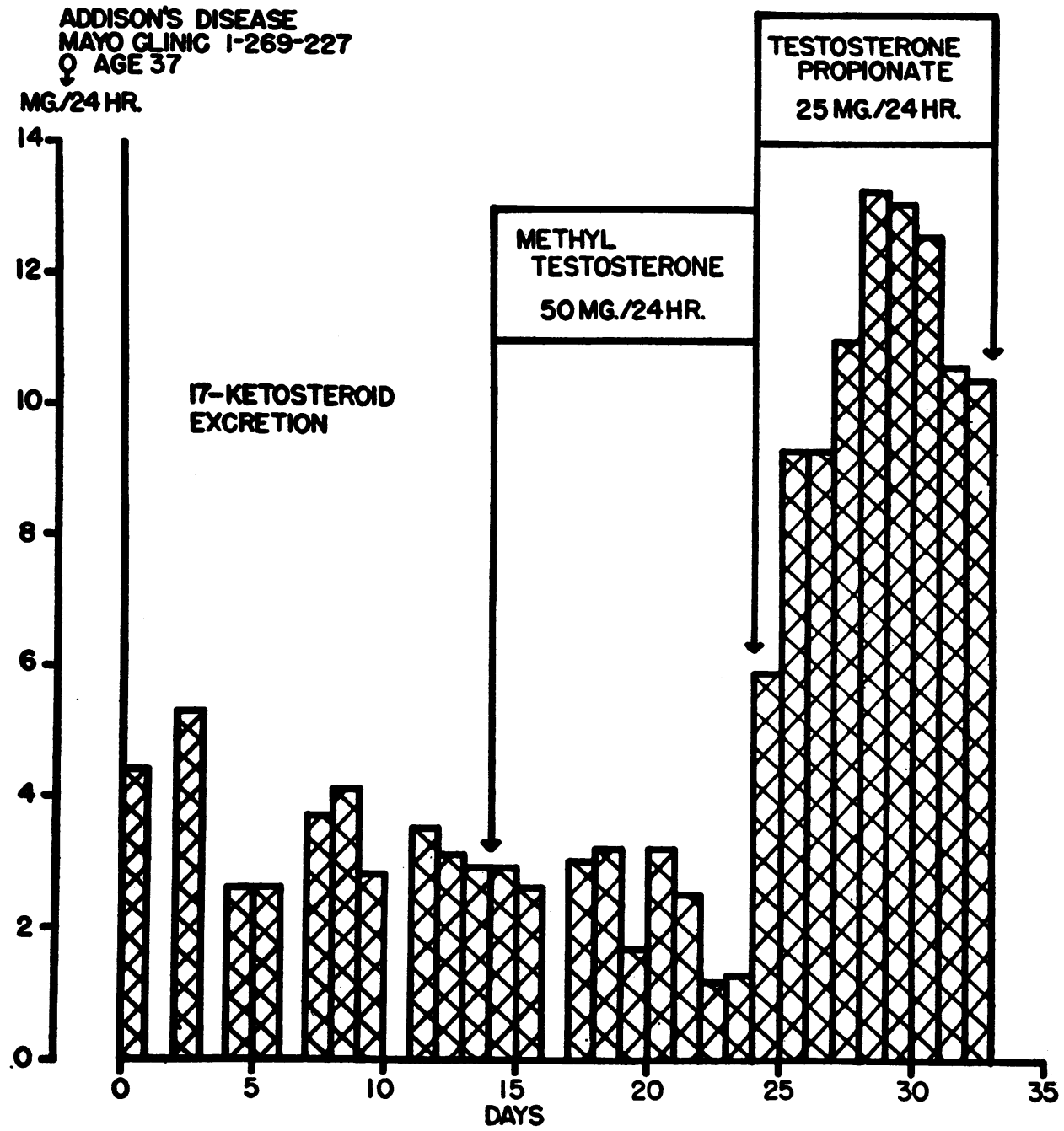

Fig. 3. Effect of Methyl Testosterone on the Urinary 17-Ketosteroid Excretion in a MAN with AdDison's Disease

This patient, Mayo Clinic No. 1-269-227, a male of 37 years, had tuberculosis of the adrenals. The data on this patient were made available through the courtesy of Dr. Edwin J. Kepler, Rochester, Minnesota (10), to whom the authors are greatly indebted. During the first 6 days of the experiment, the patient received 10 grams of sodium chloride and 5 grams of sodium citrate by mouth daily; during the remainder of the experiment he was given $4 \mathrm{mgm}$. of desoxycorticosterone acetate each day intramuscularly. This therapy had no effect on the $17-k e t o s-$ teroid excretion. It will be noted that during the control period the 17-ketosteroid excretion was low (a mean of $3.5 \mathrm{mgm}$. per $24 \mathrm{hrs}$.) compared with the normal level in males (circa 14 mgm. per 24 hrs. (1)), and that under methyl testosterone therapy the level was suggestively lower (a mean of $2.1 \mathrm{mgm}$. per $24 \mathrm{hrs}$.). The values for the first 6 days following a change in therapy were omitted in compiling the mean values. Note that the measurements were made on 24-hour collections.

\section{METHODS}

The 17-ketosteroid content of the urine was measured by a method based on a modification (15) of the Zimmermann reaction (16) that has been described previ- ously (1). To correct the result for color introduced by chromogens, the reaction is read through a green and a violet filter, and a color correction equation applied. The method is accurate within 1 to $2 \mathrm{mgm}$. in repeated analyses of the same urine pool. Normal females ex- 
MG. $124 \mathrm{HR}$.

\section{CUSHING'S SYNDROME 1.6., 9 , AGE II}

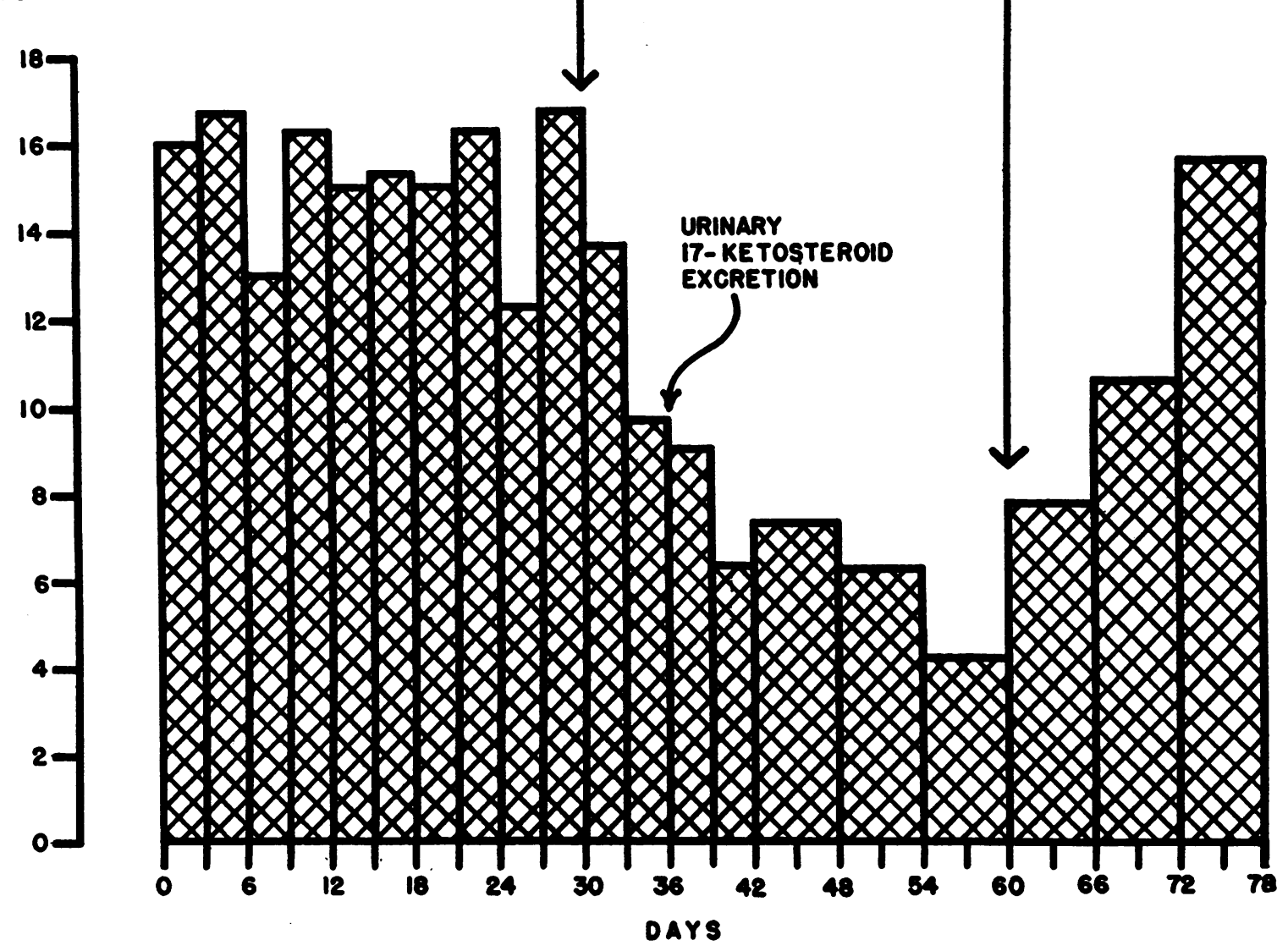

Fig. 4. Effect of Methyl Testosterone Therapy on the Urinary 17-Ketosteroid - Excretion in Case 1, a Girl with Cushing's Syndrome

For discussion, see text. Note that the measurements were made on 72 -hour collections until day 42 and on 144hour collections thereafter.

crete from 5 to 14 (average 9), normal males from 8 to 23 (average 14) mgm. of sterone per 24 hours (1).

The collection of urine specimens was rigidly supervised to insure accuracy. Cases 1, 3, and 6 were studied on the research ward, and their collections were handled by specially trained personnel. Most of the determinations in these 3 cases were made on aliquots of 72 to 144-hour pools. The other patients in this investigation collected their specimens at home and brought them personally to the laboratory; these individuals were instructed carefully in the method of collection and were questioned frequently to be certain that they followed the method accurately. Most of the determinations in these patients were on specimens that were obtained by pooling in the laboratory two accurately timed night collections. All of the results are reported in terms of amounts per 24 hours.
Methyl testosterone was administered to the patients by mouth in the form of $10 \mathrm{mgm}$. tablets.

\section{RESULTS}

In Case 1, I. G., No. 350260, a girl of 11 years with classical Cushing's syndrome, the effect of methyl testosterone was studied twice (Figures 4 and 5). It will be noted that during both control periods, the 17-ketosteroid excretion (circa $15 \mathrm{mgm}$. per 24 hours) was very high for her age (normal, circa 1 to $3 \mathrm{mgm}$. per 24 hours (17)) and quite constant; that under methyl testosterone therapy the excretion showed a very orderly fall to

\footnotetext{
4 Further clinical data are published elsewhere (9).
} 


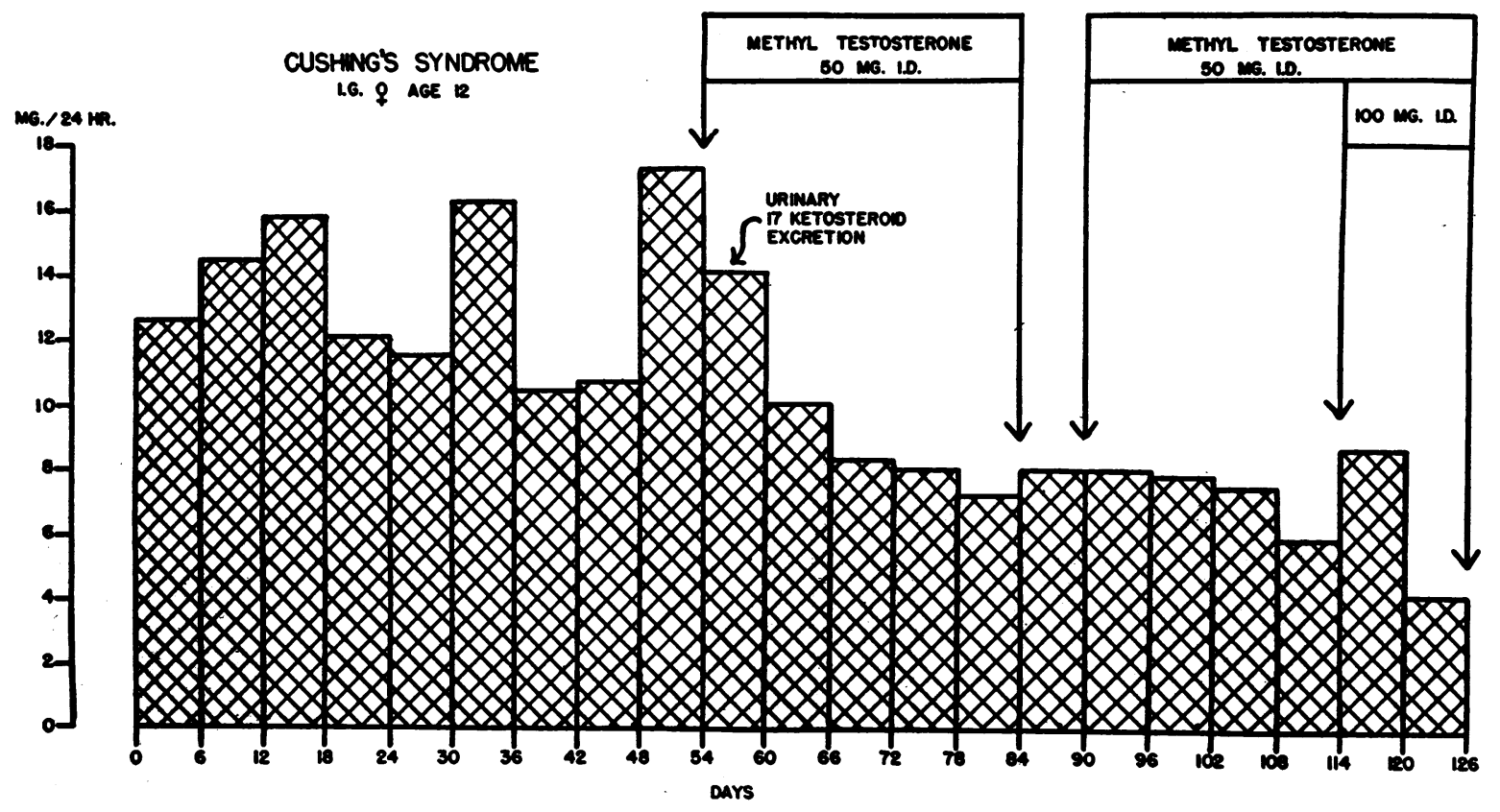

Fig. 5. Case 1, Repeat Experiment

For discussion, see text. Insulin, 25 to 100 units daily, was given intramuscularly from day 18 to day 42 . Note that the measurements were made on 144-hour collections.

a considerably lower value (circa 4 mgm. per 24 hours); that, when the therapy was omitted, the excretion again rose.

In Case 2, ${ }^{5}$ R. B., No. 3397, a woman of 53 years, also suffering from Cushing's syndrome, it will be observed (Figure 6) that the average pretreatment excretion (circa $18 \mathrm{mgm}$. per 24 hours) was high for an adult woman (normal circa 9 mgm. per 24 hours (1)) and very constant; that the excretion rose both with testosterone propionate and with dehydroisoandrosterone acetate; that under methyl testosterone therapy the excretion showed a gradual fall to a low value (circa $2 \mathrm{mgm}$. per 24 hours); and that, after discontinuation of methyl testosterone therapy, the excretion again rose to the pre-treatment level.

In Case 3, R. H., No. 401611, a girl of 6 years with congenital adrenogenital syndrome and pseudohermaphroditism, it will be noted (Figure 7) that during the control period, the 17-ketosteroid excretion (circa $15 \mathrm{mgm}$. per 24 hours) was very high for her age; that under methyl testosterone therapy the excretion showed a steady fall to a lower value (circa $10 \mathrm{mgm}$. per 24

\footnotetext{
5 Further clinical data are published elswhere $(1,9,18)$.
}

hours); and that after the therapy was omitted the excretion definitely increased.

In Case $4,{ }^{\circ}$ E. F., No. 240632, a woman of 24 years with a condition similar to Case 3 , the average 17-ketosteroid excretion (Figure 8) (circa $45 \mathrm{mgm}$. per 24 hours) was very high during the control period; with methyl testosterone therapy the average level (circa $35 \mathrm{mgm}$. per 24 hours) was suggestively lower; and, when the drug was discontinued, the average excretion (circa $40 \mathrm{mgm}$. per 24 hours) was increased.

Case 5, A. S., a woman of 34 years, had no disease, and normal function of the adrenal cortex. It will be observed (Figure 9) that during the control period the average 17-ketosteroid excretion (circa $11.5 \mathrm{mgm}$. per 24 hours) was slightly above the average for an adult woman (normal, circa $9 \mathrm{mgm}$. per 24 hours (1)); that during the administration of $20 \mathrm{mgm}$. of methyl testosterone daily, the 17-ketosteroid excretion tended to be lower; that during the administration of $40 \mathrm{mgm}$. of methyl testosterone daily, the excretion showed a gradual fall to definitely low values (circa 6 mgm. per 24 hours); and that after discontinua-

\footnotetext{
6 Further clinical data are published elsewhere (1).
} 


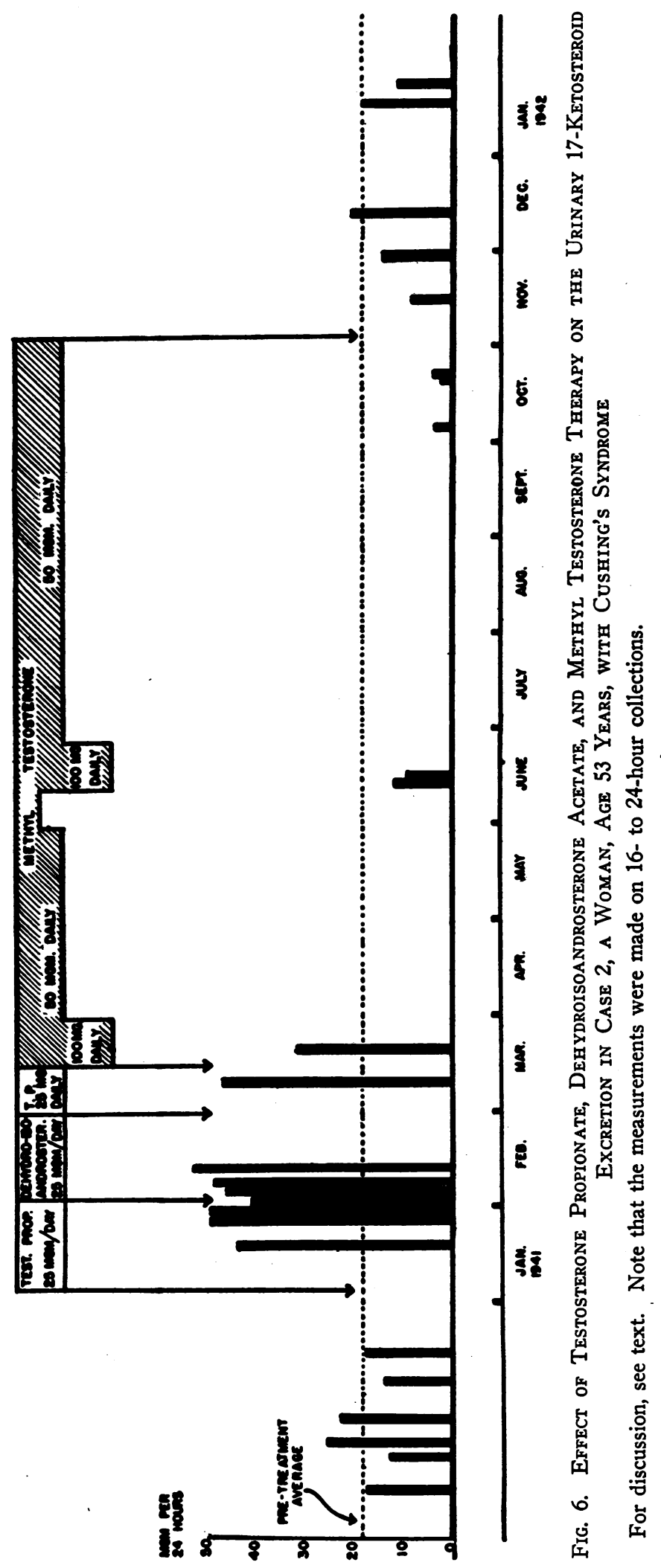




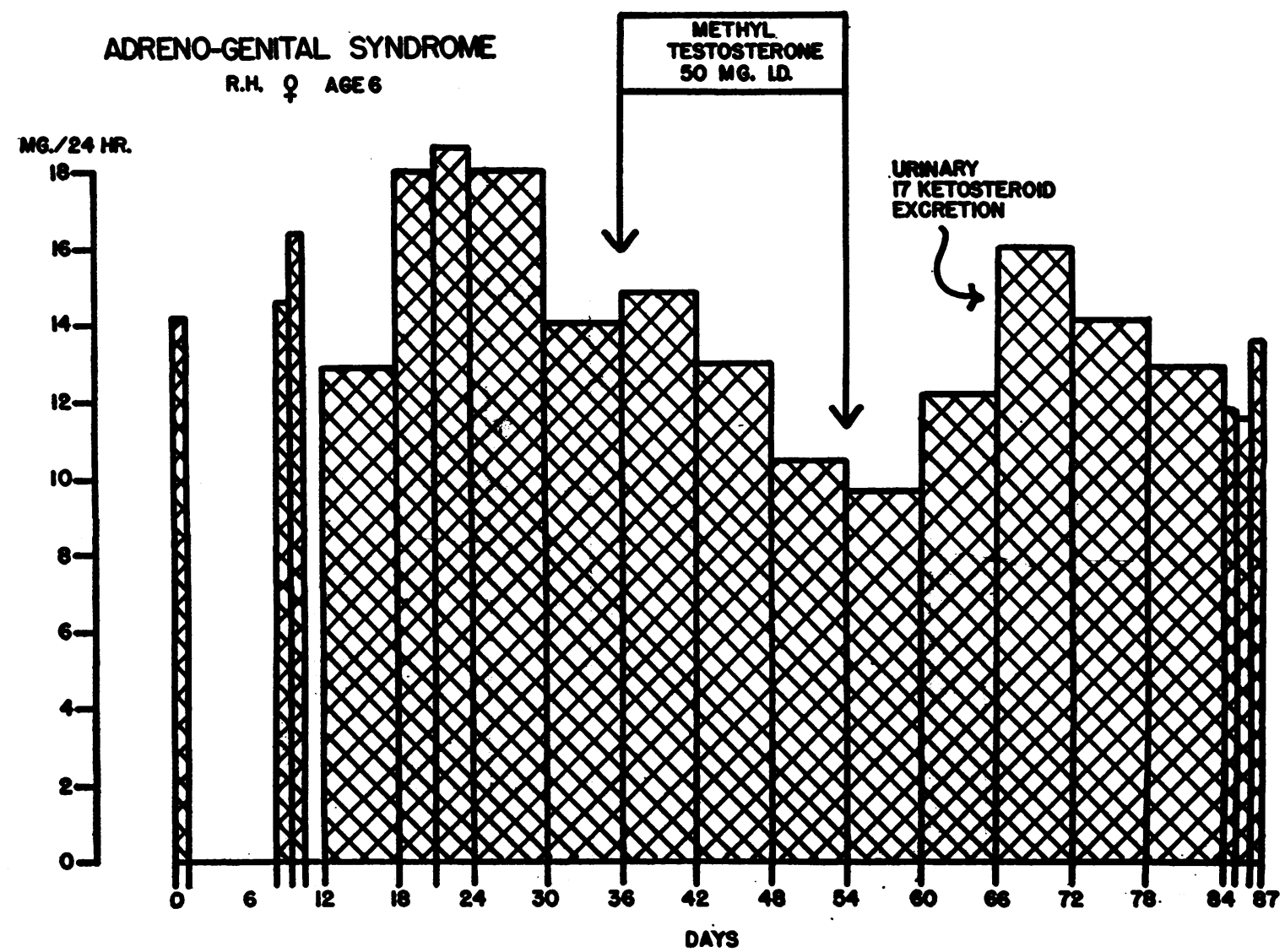

Fig. 7. Effect of Methyl Testosterone Therapy on the Urinary 17-Ketosteroid Excretion in Case 3, a Girl with Adrenogenital Syndrome

For discussion, see text. Desoxycorticosterone acetate, $10 \mathrm{mgm}$. daily, was given intramuscularly from day 66 to day 86. This therapy had no effect on the 17 -ketosteroid excretion. Note that the measurements were made on 24-hour collections for the first 3 and the last 3 determinations, on 72-hour collections for days 18 to 24, and otherwise on 144-hour collections.

tion of methyl testosterone therapy, the excretion again rose to the pre-treatment level.

Case 6, F. S., No. 424919, a woman of 35 years with Paget's disease (osteitis deformans), is assumed to have normal function of the adrenal cortex. It will be seen (Figure 10) that, during the control period, the $17-$ ketosteroid excretion (circa $8 \mathrm{mgm}$. per 24 hours) was approximately average for an adult woman (normal circa $9 \mathrm{mgm}$. per 24 hours (1)) ; and that under methyl testosterone therapy the level (circa $6 \mathrm{mgm}$. per 24 hours) was moderately but hardly significantly lower.

Case 7, F. B., No. 84187, a man of 27 , had before any specific treatment a high voice, small larynx, no beard, rudimentary prostate, absence of testes in scrotum, moderately well developed phallus, axillary and pubic hair absent, scant hair on extremities, absence of recession of hair in temporal regions, and obesity. Bilateral rudimentary testes were found at operation at age of 8. The pituitary gonadotropic (follicle-stimulating) hormone in the urine (between 567 and 868 mouse units per 24 hours) was very high compared with the normal (less than 104 mouse units per 24 hours (19)). The excretion of 17-ketosteroids (circa 16 to $33 \mathrm{mgm}$. per 24 hours) was also high. It will be noted (Figure 11), that two experiments were carried out on this patient with different doses of methyl testosterone. The control values (circa $24 \mathrm{mgm}$. per 24 hours) were high; during the administration of $100 \mathrm{mgm}$. of 


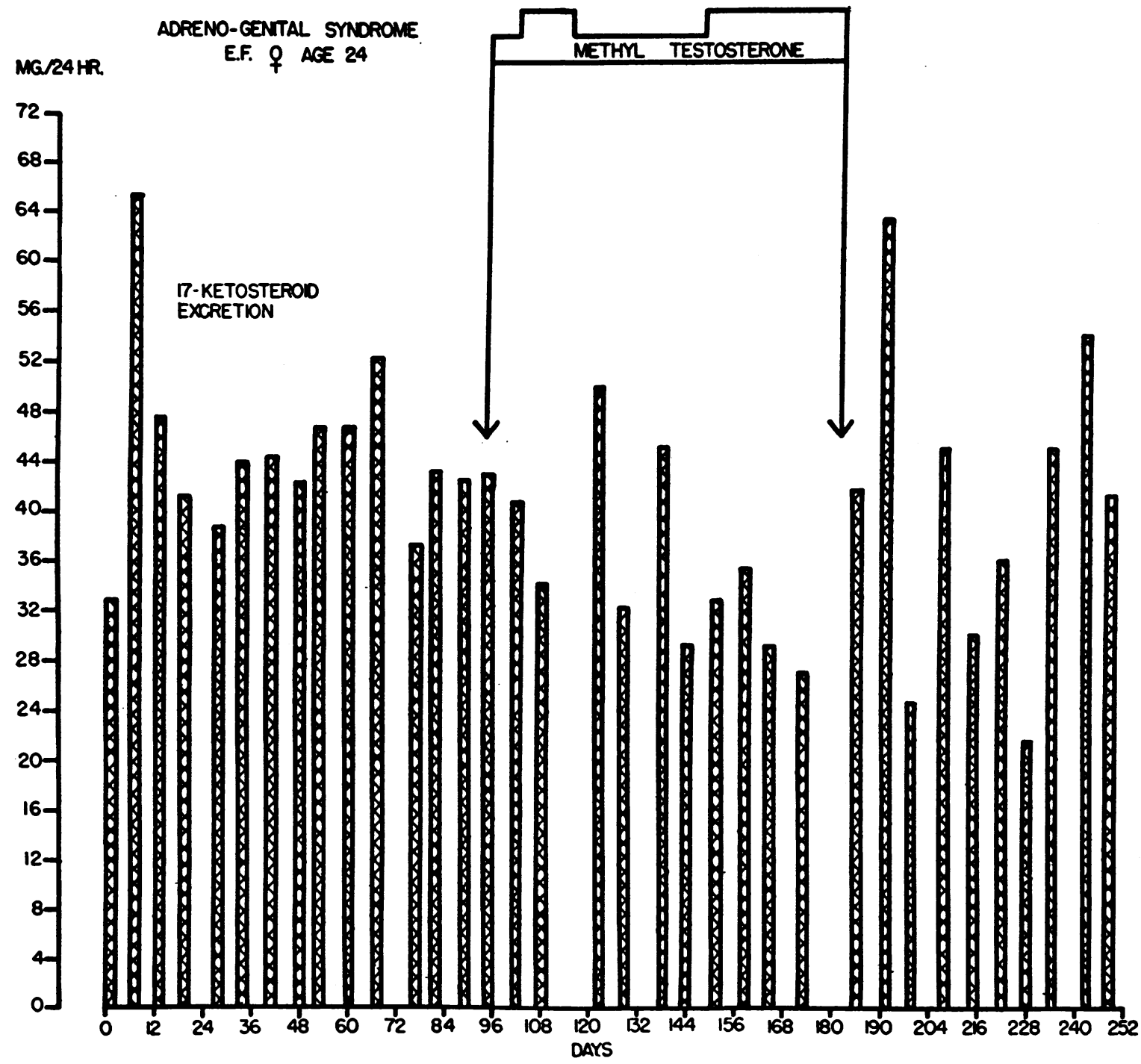

Fig. 8. Effect of Methyl Testosterone Therapy on the Urinary 17-Ketosteroid Excretion in Case 4, a Woman with Adrenogenital Syndrome

For discussion, see text. Note that the measurements were made on 24-hour collections.

methyl testosterone daily there was a fall to a lower level (circa $19 \mathrm{mgm}$. per 24 hours) ; during the 14 days after the cessation of therapy, the level (circa $18 \mathrm{mgm}$. per 24 hours) continued low. This experiment was considered inconclusive and so was repeated with larger doses. During the administration of $200 \mathrm{mgm}$. of methyl testosterone daily, the 17-ketosteroid excretion (circa $10 \mathrm{mgm}$. per 24 hours) was definitely lower than the initial values (circa $24 \mathrm{mgm}$. per 24 hours) or the intervening control values (circa $18 \mathrm{mgm}$. per 24 hours); from the 14 th to 27 th day following ces- sation of treatment, the level (circa $18 \mathrm{mgm}$. per 24 hours) was significantly higher. It will be noted in Figure 11 that chorionic gonadotropin (A.P.L.) was administered on two occasions. Although this therapy may have induced a transitory rise in the 17-ketosteroid excretion, this possibility has been ignored in compiling the mean values obtained during methyl testosterone therapy (Table I).

The data from these studies are summarized in Table I. Since there is a delay in the onset and in the cessation of effect following the adminis- 


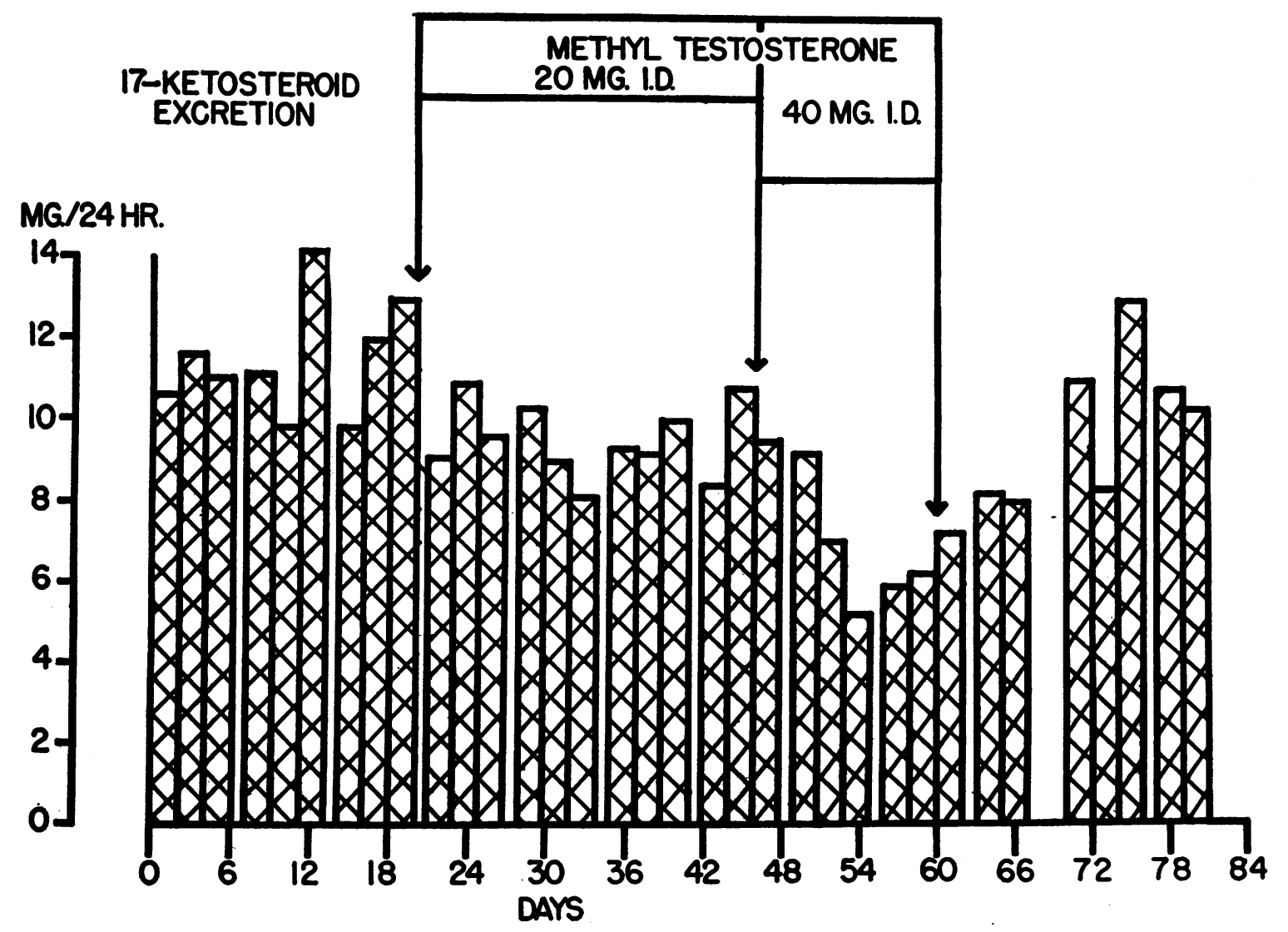

Fig. 9. Effect of Methyl Testosterone Therapy on the Urinary 17-Ketosteroid Excretion in Case 5, a Normal Woman, Age 34 Years

For discussion, see text. Note that the measurements were made on 24-hour collections.

tration of methyl testosterone, the values for the first 6 days following a change in therapy were omitted in compiling the mean values. In the 9 experiments, the 7 patients had an average excretion of $18.7 \mathrm{mgm}$. of steroid per 24 hours before, $11.9 \mathrm{mgm}$. during, and $18.4 \mathrm{mgm}$. after methyl testosterone administration.

\section{DISCUSSION}

The possibility that the decrease in the urinary 17-ketosteroid level during the administration of methyl testosterone is fortuitous and unrelated to the therapy is almost eliminated by the following points: (a) there is a direct relationship between the fall in level and the administration of the therapy, which is clear-cut in Case 1 (both experiments), Case 2, Case 3, Case 5, and Case 7 (Experiment 2$)$; $(b)$ there is a tendency toward a fall in the excretion in all of the other experi- ments (including the studies of the two males with Addison's disease, and of the male with normal function of the adrenals and of the testes); (c) the fall in the level is gradual suggesting a physiologic alteration rather than a chance variation; (d) there is a rebound to higher or pre-treatment levels with cessation of therapy in all of the experiments in which these studies were made except Experiment 1, Case 7; and (e) the amount of decrease (circa 40 to 60 per cent) in excretion in Case 1 (both experiments), Case 2, Case 3, Case 5, and Case 7 (Experiment 2) significantly exceeds both the technical errors of the method (vide supra) and the amount of unexplained day to day variation (not more than 25 per cent and usually less (20)) that we have encountered elsewhere. For example, 17 assays on one male individual gave an average excretion of $12.9 \mathrm{mgm}$. per 24 hours with a deviation of $\pm 1.5 \mathrm{mgm}$. or 
\pm 12.6 per cent per 24 hours (21). In view of these considerations, it is concluded that the decrease in the urinary 17-ketosteroid level during the administration of methyl testosterone is due to the action of this compound.

Much of the argument to follow depends on the assumption that the 17 -ketosteroid excretion in the urine can be used as an index but not a measure of " $N$ " hormone production. We have elsewhere (9) reviewed the considerable circumstantial evidence that the urinary 17 -ketosteroids are : (a) largely derived from "N" hormones, and (b) only slightly, if at all, from " $\mathrm{S}$ " hormones. We will cite here only one piece of evidence for each of these suppositions. Thus, on the one hand, testosterone (a strong " $\mathrm{N}$ " hormone) is excreted largely as androsterone and etiocholanolone both of which are 17-ketosteroids; on the other hand, pre-pubertal children, who in all probability have a normal " $S$ " hormone production, excrete negligible amounts of 17 -ketosteroids in the urine.

The experiments herein reported indicate that methyl testosterone interferes with the adrenal cortical mechanism for producing urinary 17 ketosteroids or their precursors. Such an interference might be produced in at least two ways; (a) a direct inhibition by methyl testosterone of

TABLE I

Effect of methyl testosterone on urinary 17-ketosteroid excretion

\begin{tabular}{l|c|c|c}
\hline \multirow{2}{*}{ Case No. } & \multicolumn{3}{|c}{ Average excretion } \\
\cline { 2 - 4 } & Before & During * & After * \\
\hline & \multicolumn{3}{|c}{ mgm. per 24 hours. } \\
Case 1, Exp. 1 & 15.3 & 6.1 & 13.0 \\
Case 1, Exp. 2 & 13.5 & 7.6 & 16.3 \\
Case 2 & $18.7 \dagger$ & 5.9 & 13.2 \\
Case 3 & 15.8 & 11.8 & 10.1 \\
Case 4 & 42.8 & 34.5 & 10.2 \\
Case 5 & 11.5 & $6.1 \ddagger$ & 18.4 \\
Case 6 & 7.6 & $18.8 \S$ & 18.0 \\
Case 7, Exp. 1 & 24.2 & 10.08 & 17.7 \\
Case 7, Exp. 2 & 11 & 11.9 & 18.4 \\
\hline Average & 18.7 & 17 & \\
\hline
\end{tabular}

* Values during first 6 days after change in therapy omitted.

† Control level before any treatment.

$\ddagger$ Average during administration of $40 \mathrm{mgm}$. per day. 8 Values during chorionic gonadotropin therapy included in calculating the average excretion (see Figure 11).

II Experiment 2 immediately followed the after-period of Experiment 1 (see Figure 11).

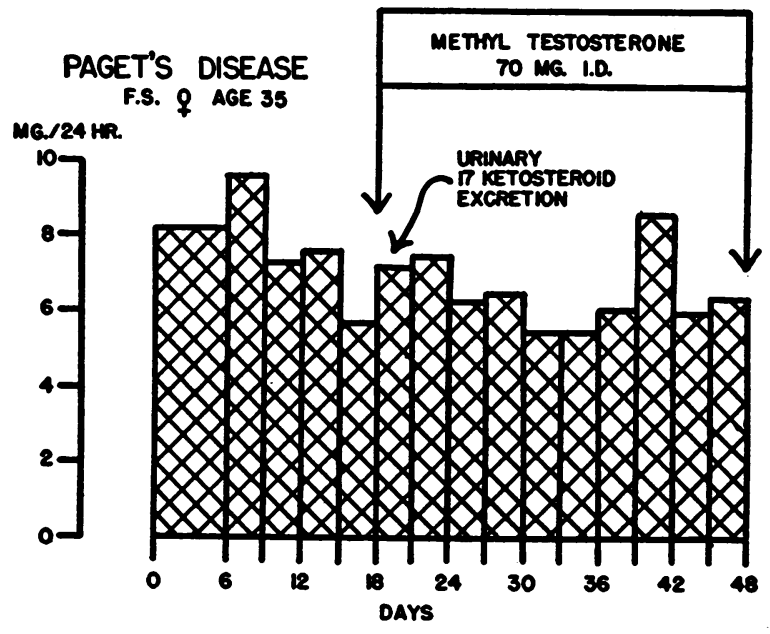

Fig. 10. Effect of Methyl Testosterone Therapy on the Urinary 17-Ketosteroid Excretion in Case 6, a Woman with Paget's Disease of Bone (Osteitis DEFORMANS)

For discussion, see text. Note that the measurements were made on a 144-hour collection for days 1 to 6 , and on 72-hour collections thereafter.

the adrenal cells which produce 17 -ketosteroids or their precursors, or $(b)$ an indirect inhibition of these cells by decreasing the production of some tropic hormone (or hormones) by the anterior pituitary. Animal experimentation favors the latter instead of the former thesis, since it has been shown (22) that the atrophy of the adrenal cortex induced by testosterone therapy does not occur in pituitarectomized animals receiving adrenal corticotropic hormone. This is analagous to experiments of others (6) in which the damaging effects of testosterone on the Leydig cells could not be produced in pituitarectomized animals in which the Leydig cells were maintained by chorionic gonadotropin (a hormone very similar, if not the same, as the luteinizing hormone).

In the case of the male gonad, the tropic hormone in question is the luteinizing hormone, $\mathrm{LH}$. Since it has been here shown that methyl testosterone inhibits the 17 -ketosteroid production by the adrenal cortex and since the same is thought to be true for the male gonad, these experiments may add one more piece of evidence to that obtained elsewhere (vide infra) that the production of 17 -ketosteroids or their precursors from both these organs is stimulated by the same tropic hormone, namely $\mathrm{LH}$. 


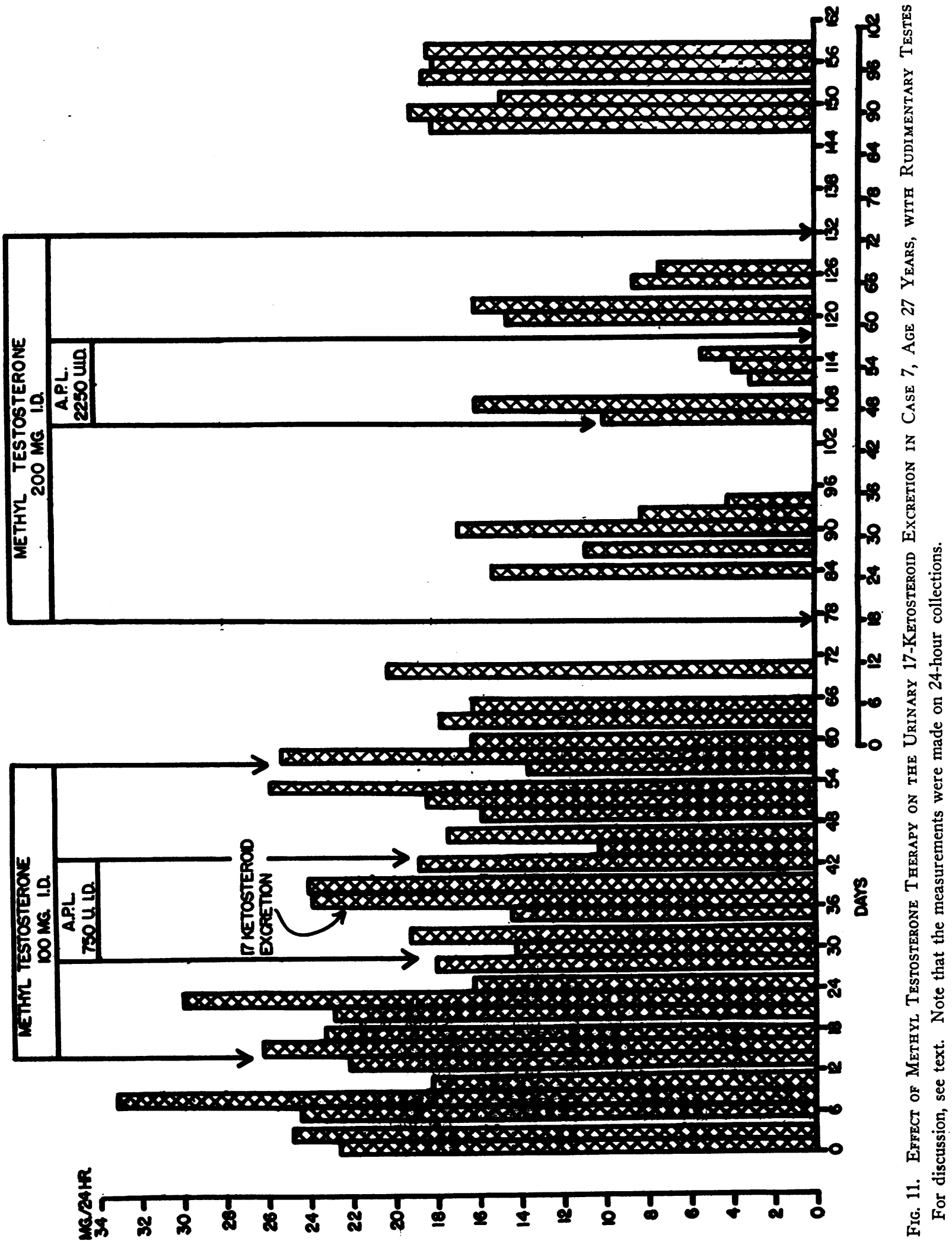


In Figure 12, an attempt is made to show these hormonal relationships schematically in a normal individual; in Figure 13, attempts are made to show these relationships both before and after the administration of methyl testosterone in a normal individual, a female patient with Cushing's syndrome, a female patient with adrenogenital syndrome, and a male patient with Addison's disease.

There is evidence, besides that here presented, that one tropic hormone of the pituitary stimulates in the male both the cells of the adrenal cortices concerned with the production of 17-ketosteroids and the cells of Leydig. In a previous paper from this clinic (14), it was pointed out that those eunuchoid patients (the minority) with high titers of follicle-stimulating-hormone in the urine had 17-ketosteroid excretions of the order of magnitude of those seen in normal females. The inference was that these patients suffered from a primary underfunction of the gonads (i.e., eunuchs from an endocrine point of view) with normal function of the adrenal cortices. It was further shown that those eunuchoid patients (the majority) who did not have a high titer of folliclestimulating-hormone in the urine had 17-ketosteroid excretions considerably lower than those in the normal female; the inference was that such patients were suffering from a defective production of 17-ketosteroids in both the adrenal cortices and the testes. This suggested that one hormone stimulated both organs (see Figure 12). Furthermore, the failure of bilateral orchidectomy in patients with metastatic cancer of the prostate to lower the 17-ketosteroid excretion (24) is in accord with the suggestion that such a procedure removes an inhibitor to the tropic hormone in question and that the resulting increased production of said tropic hormone stimulates increased production of 17 -ketosteroids in the adrenal cortices.

Similarly, the observation that the 17-ketosteroid excretion of young adult females tends to rise for a year or more following termination of ovarian function by castration or x-radiation (25, 26) favors the same interpretation. The demonstration that there is a rise in the urinary excretion of luteinizing hormone in the menopausal state (27) also is in accord with the suggested hypothesis.

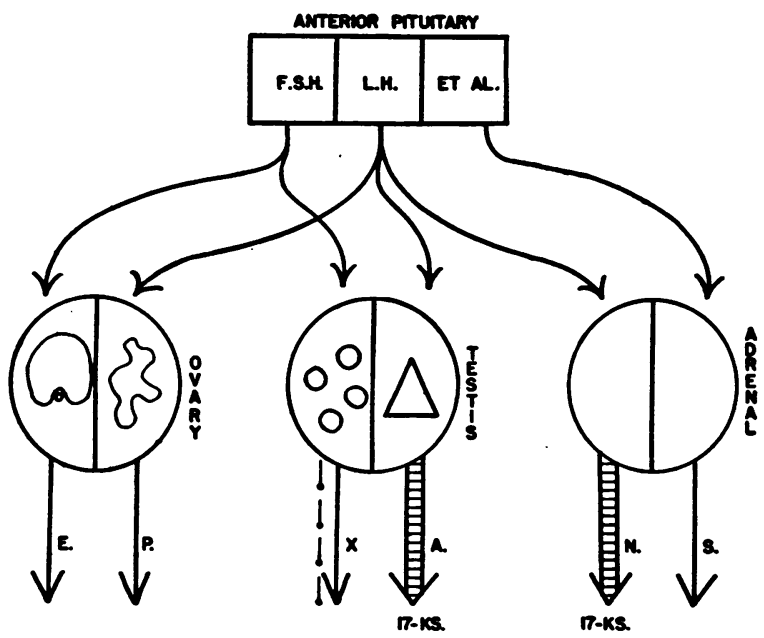

Fig. 12. Schematic Diagram to Show Normal Relationship Between Anterior Pituitary Tropic Hormones and Tissues Producing 17-Ketosteroid PreCURSORS

The pituitary is divided into three compartments: FSH for follicle-stimulating-hormone, LH for luteinizing hormone, and "et al." for remaining hormones. The authors are not certain whether the compartment marked LH should not also include luteotrophin. Striped arrows are used to represent 17-ketosteroid hormones. E-estradiol ; $\mathrm{P}$-progesterone; $\mathrm{X}$-hypothetical hormone produced by tubules of testes (23); A-androgen (testosterone); $\mathrm{N}$ "N hormone" (see text); S- "S hormone" (see text).

Other circumstantial evidence that the luteinizing hormone stimulates 17 -ketosteroid production by the adrenal cortex is summarized in the following paragraphs. Further discussion of the findings that support these contentions, as well as of a small amount of data that do not, may be found elsewhere $(28,29)$.

Atrophy of the adrenal cortex has been produced in animals by the administration of testosterone $(22,30$ to 40$)$ and progesterone $(22,38$, $41,42)$; while hypertrophy of the cortex has resulted from treatment with estrogens (43 to 59). These effects cannot be produced in hypophysectomized animals in which the adrenal cortex is maintained in a normal state by the administration of adrenocorticotropic hormone $(22,45,52,60)$. This is evidence that the effects of testosterone, progesterone, and estrogens on the adrenal cortex are brought about through the pituitary. It has been shown that testosterone $(6,38,61,62)$ and progesterone (63 to 66 ) inhibit the production of luteinizing hormone $(\mathrm{LH})$ by the anterior 


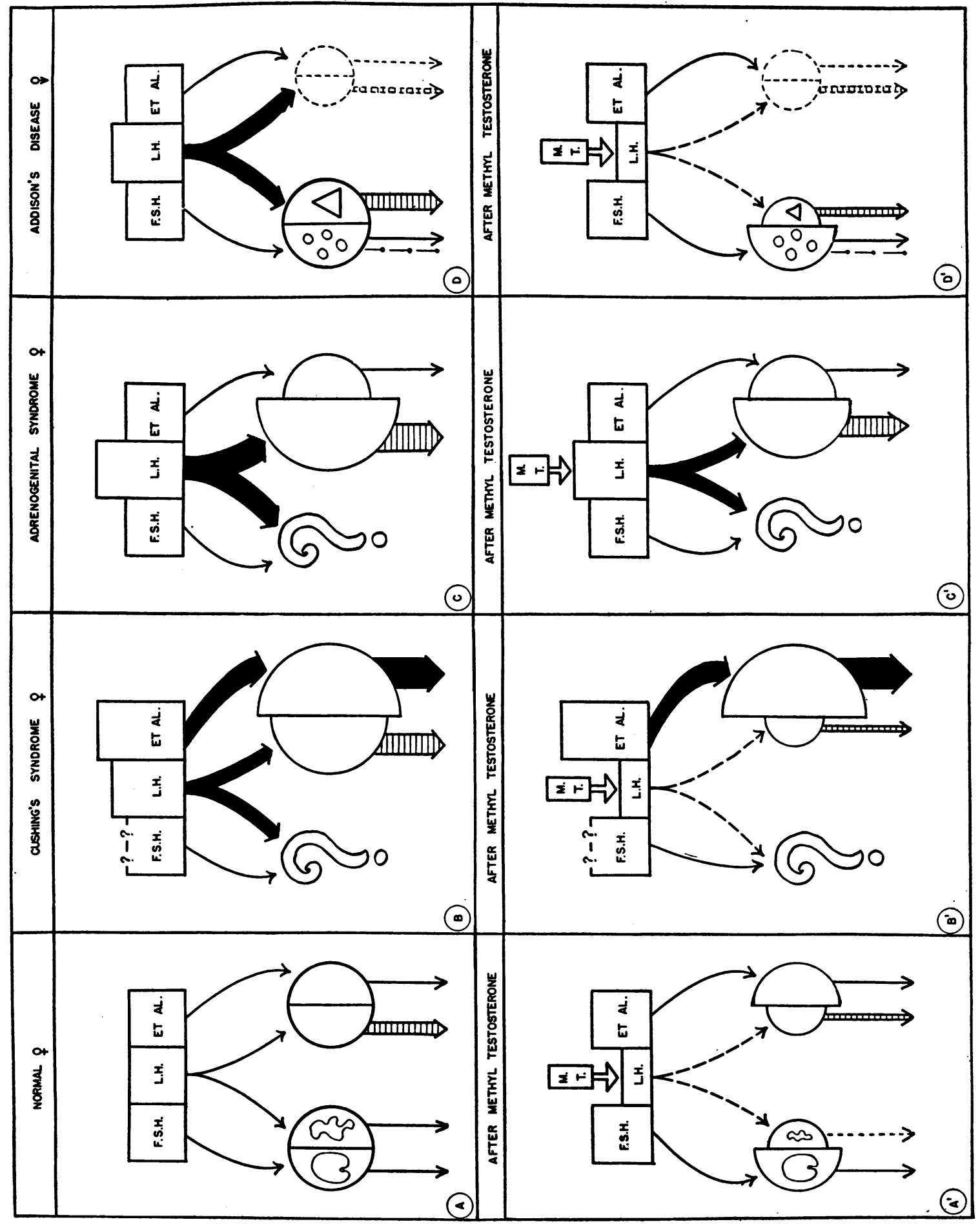




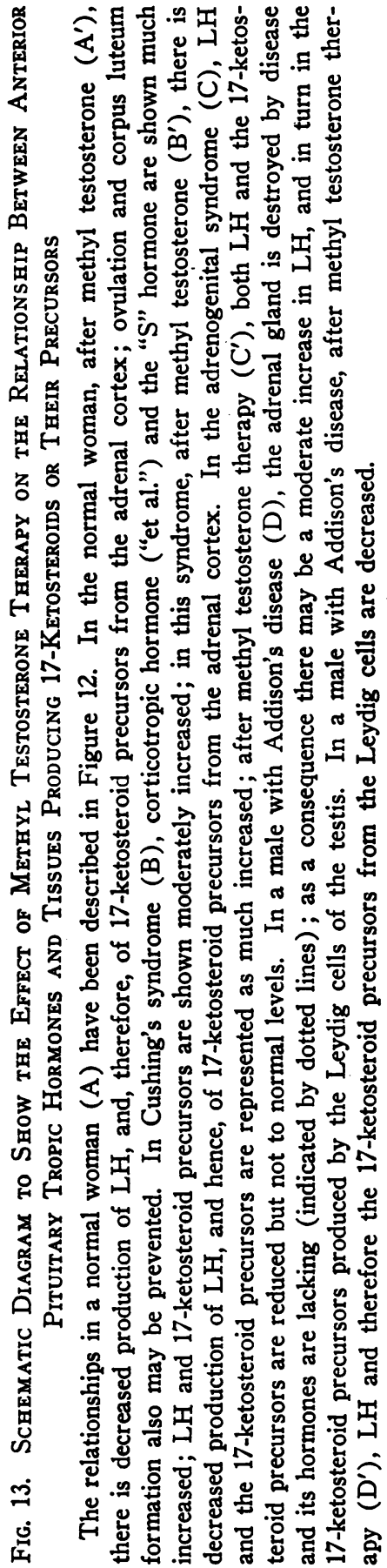

pituitary, while estrogens (45, 67 to 69 ) increase the production of $\mathrm{LH}$. Hypertrophy of the adrenal cortex has been produced by the administration of LH (70), or by substances very analagous to it, such as chorionic gonadotropin (70 to 75) and the gonadotropic principle of pregnant mares' serum $(70,76)$; presumably atrophy of the adrenal cortex may result from the lack of LH. Further evidence is obtained from the effects of removal of the gonads. Gonadectomy results in an increase in the gonadotropic activity of the pituitary gland $(77,78)$. Gonadectomy also causes hypertrophy of the adrenal cortex $(12,13,22,50,79$ to 88$)$. This hypertrophy of the adrenal cortex can be made to atrophy by testosterone $(22,34,78,83,87,89,90)$ and by progesterone $(22,87)$; and to increase by estrogens $(58,88)$. These facts make very attractive the assumption that $\mathrm{LH}$ exerts an effect on the adrenal cortex which is characterized by an hypertrophy of the cortex when LH production is excessive, and by an atrophy of the cortex when $\mathrm{LH}$ production is diminished below normal.

The question then arises whether the alterations in the adrenal cortex that are attributed to changes in the production of $\mathrm{LH}$ by the pituitary cannot be attributed equally well to changes in the production of adrenocorticotropic hormone (ACTH) of the pituitary, since ACTH also exerts an effect on the adrenal cortex which is characterized by a hypertrophy of the cortex when ACTH production is excessive $(50,80,91$ to 105$)$ and by an atrophy of the cortex when ACTH production is diminished below normal (106 to 116). Against this assumption are the following facts: (1) distinct differences can be be demonstrated histologically between the hypertrophy of the adrenal cortex produced by the two mechanisms, since in hypophysectomized animals no restoration of the lipoid content and no disappearance of the sudanophobe zone occurs after the administration of LH $(52,76)$ and estrogens $(52,76)$, while a disappearance of the sudanophobe zone and restoration of the lipoid content occurs after the administration of ACTH $(52,76,101)$; and (2) hypertrophy of the adrenal cortex has been produced by $\mathrm{LH}$ preparations that contain insignificant amounts of $\mathrm{ACTH}(52,70,76)$, and vice versa (99 to 105). These facts favor the assump- 
tion that both LH and ACTH affect the adrenal cortex, but not in the same manner.

The strength of the evidence derived from the animal experiments cited above would be increased if it could be shown that alterations in the size of the adrenal cortex were correlated with changes in the excretion of 17 -ketosteroid or androgenic substances. In most of these investigations, this evidence has not been sought. Pertinent to this discussion, however, are the observations of certain investigators $(117,118)$ who were able to produce significant enlargement of the seminal vesicles and prostates of castrated rats by means of pituitary extracts which also caused hypertrophy of the adrenal cortices. Since the effect could not be elicited in the absence of the adrenals, it is clear that this gland had been stimulated to secrete an androgenic principle. Another author (119) obtained similar results in castrated male guinea pigs, and also observed a masculinizing effect (hypertrophy of the clitoris) with pituitary extracts in ovariectomized females. Studies to demonstrate directly in man the effect of chorionic gonadotropin on the production of 17-ketosteroids by the adrenal cortex are being conducted.

Since the luteinizing hormone in the female stimulates the production of progesterone (120), it might be anticipated that large doses of progesterone (like methyl testosterone) would inhibit 17-ketosteroid production from both the adrenal cortices and the male gonads; studies to answer this question also are being conducted.

The evidence here presented suggests that the high 17-ketosteroid excretion in the adrenogenital syndrome is less easily influenced by methyl testosterone than is that in Cushing's syndrome, even though the pathology in both instances is hyperplasia of the adrenal cortices. This finding is consistent with the thought, already expressed elsewhere (9), that the increased 17-ketosteroid production in Cushing's syndrome is compensatory to the primary pathology which is an increased production of the " $S$ " hormone; such being the case, one would anticipate that when an exogenous source of " $N$ " hormone was made available in the form of methyl testosterone, the endogenous production would quickly recede. In the adrenogenital syndrome, on the other hand, the primary cause of pathology is thought to be a hyperplasia of those cells which produce "N" hormone, and one would anticipate that it would be harder to modify a process which is primary than one which is secondary.

From the clinical point of view, however, the important point is that the over-production of " $\mathrm{N}$ " hormone in the adrenogenital syndrome can be reduced. This may be a clue to therapy. Needless to say it is of little value to such a patient to have her endogenous " $\mathrm{N}$ " hormone production decreased by taking an exogenous source of " $N$ " hormone. However, if a steroid could be found which inhibits the endogenous source without itself being an androgen, an important advance in the therapy of these unfortunate patients would probably be at hand. Progesterone has not had a beneficial effect in moderate doses $(5,121)$; it is to be hoped that it may have in very large doses. In any case, the authors feel very strongly that the approach to the problem is in this direction, as nothing is to be gained by subtotal resection of the adrenal cortices (122, 123).

\section{SUMMARY AND CONCLUSIONS}

1. Since 17 -methyl testosterone is not excreted as a 17 -ketosteroid, it was employed to study the effect of a testosterone compound on the endogenous production of urinary 17-ketosteroids of adrenal origin.

2. The administration of methyl testosterone decreased the urinary 17 -ketosteroids of 7 patients in whom the only source of these substances was the adrenal cortices. The patients included: 2 women with adrenal hyperplasia and Cushing's syndrome, 2 women with adrenal hyperplasia and adrenogenital syndrome, 2 women with normal cortical function, and 1 man with adrenal hyperplasia and congenital absence of functioning testicular tissue.

3. The administration of methyl testosterone caused a suggestive but not conclusive decrease in the urinary 17-ketosteroids of 2 male patients with Addison's disease in whom the only source of these substances was the testes.

4. Since the production of $17-$ ketosteroids or their precursors by both the adrenal cortex and the male gonad appears to be inhibited by methyl testosterone, it is suggested that the mechanism of inhibition is the same for both glands. 
5. This inhibition is attributed to a decreased production of some pituitary tropic hormone, as suggested by animal experiments in the literature. If one accepts this hypothesis, the findings here reported support the thesis that the same tropic hormone, presumably the luteinizing hormone, stimulates both glands.

6. The 17-ketosteroid excretion by patients with the adrenogenital syndrome was less easily influenced by methyl testosterone than was that of patients with Cushing's syndrome. This is further evidence that the elevated 17-ketosteroid excretion in the former condition is a manifestation of the primary pathology, whereas the increased excretion in the latter condition is an indication of a compensatory process.

7. The fact that the $17-$ ketosteroid excretion in the adrenogenital syndrome can be reduced with methyl testosterone shows that the condition is potentially reversible and gives hope that a nonandrogenic steroid may be found which will likewise reduce the 17 -ketosteroid excretion in this condition.

The authors are indebted to Lowell D. Cox for technical assistance.

\section{BIBLIOGRAPHY}

1. Fraser, R. W., Forbes, A. P., Albright, F., Sulkowitch, H., and Reifenstein, E. C., Jr., Colorimetric assay of 17 -ketosteroids in urine. A survey of the use of this test in endocrine investigation, diagnosis and therapy. J. Clin. Endocrinol., 1941, 1, 234.

2. Callow, N. H., Callow, R. K., and Emmens, C. W., The effect of the administration of testosterone propionate on the urinary excretion of compounds allied to the steroid hormones. J. Endocrinol., 1939, $1,99$.

3. a. Wilkins, L., Fleischmann, W., and Howard, J. E., Read before Am. Ped. Soc., May 2, 1942.

b. Wilkins, L., Conference on Metabolic Aspects of Convalescence Including Bone and Wound Healing. Minutes of Fourth Meeting, June 11-12, 1943, p. 149, distributed by Josiah Macy, Jr. Foundation, New York.

c. Wilkins, L., Idem, Minutes of Fifth Meeting, October 8-9, 1943, p. 132.

4. Talbot, N. B., Butler, A. M., and MacLachlan, E. A., The effect of testosterone and allied compounds on the mineral, nitrogen, and carbohydrate metabolism of a girl with Addison's disease. J. Clin. Invest., $1943,22,583$.

5. Unpublished data.

6. Selye, H., and Friedman, S. M., Animal experiments concerning the hormonal therapy of testicular atrophy. Am. J. M. Sc., 1941, 201, 886.

7. Shay, H., Gershon-Cohen, J., Paschkis, K. E., and Fels, S. S., Inhibition and stimulation of testes in rats treated with testosterone propionate. Endocrinol., 1941, 28, 485.

8. Wells, L. J., Effects of large doses of androgen on the testis in the ground squirrel, Citellus Tridecemlineatus. Endocrinol., 1943, 32, 455.

9. Albright, F., Cushing's syndrome. Its pathological physiology, its relationship to the adrenogenital syndrome, and its connection with the problem of the reaction of the body to injurious agents ("alarm reaction" of Selye). The Harvey Lecture Series, 1942-1943, 38, 123.

10. Kepler, E. J., Personal communication.

11. Catchpole, H. R., Hamilton, J. B., and Hubert, G. R., Effect of male hormone therapy on urinary gonadotropins in man. J. Clin. Endocrinol., 1942, 2, 181.

12. Wooley, G., Fekete, E., and Little, C. C., Effect of castration in the dilute brown strain of mice. Endocrinol., 1941, 28, 341a.

13. Gardner, W. U., Estrogenic effects of adrenal tumors of ovariectomized mice. Cancer Res., 1941, $1,632$.

14. Albright, F., Forbes, A. P., Fraser, R. W., Miller, R. B., and Reifenstein, E. C., Jr., A classification of the causes of hypoleydigism. Tr. A. Am. Physicians, 1941, 56, 43.

15. Callow, N. H., Callow, R. K., Emmens, C. W., and Stroud, S. W., Methods of extracting compounds related to the steroid hormones from human urine. J. Endocrinol., 1939, 1, 76.

16. Zimmerman, W., Eine Forbreaktion der Sexualhcrmone und ihre Anwendungs zur quantitativen colorimetrischen Bestimmung. Ztschr. f. physiol. Chem., 1935, 233, 257. Also, Colorimetrische Bestimmung der Keimdrüsehormone. Ztschr. f. physiol. Chem., 1936, 245, 47.

17. Talbot, N. B., Butler, A. M., Berman, R. A., Rodriguez, P. M., and MacLachlan, E. A., Excretion of 17-ketosteroids by normal and abnormal children. Am. J. Dis. Child., 1943, 65, 364.

18. Albright, F., Parson, W., and Bloomberg, E., Cushing's syndrome interpreted as hyperadrenocorticism leading to hypergluconeogenesis; results of treatment with testosterone propionate. J. Clin. Endocrinol., 1941, 1, 375.

19. Klinefelter, H. F., Jr., Albright, F., and Griswold, G. C., Experience with a quantitative test for normal or decreased amounts of follicle stimulating hormone in the urine in endocrinological diagnosis. J. Clin. Endocrinol., 1943, 3, 529.

20. Forbes, A. P., The 17-ketosteroid excretion in stress. Preliminary report. Booklet distributed by the Josiah Macy, Jr. Foundation, New York, 1942, p. 3.

21. Reifenstein, E. C., Jr., Conferences on Ketosteroids at Hotel Seaside, Atlantic City, N. J., June 7, 1942. Booklet distributed by the Josiah Macy, Jr. Foundation, New York, 1943, p. 24. 
22. Selye, H., Compensatory atrophy of the adrenals. J. A. M. A., 1940, 115, 2246.

23. Klinefelter, H. F., Jr., Reifenstein, E. C., Jr., and Albright, F., Syndrome characterized by gynecomastia, aspermatogenesis without a-Leydigism, and increased excretion of follicle-stimulating hormone. J. Clin. Endocrinol., 1942, 2, 615.

24. Scott, W. W., and Vermeuten, C., Studies on prostatic cancer. V. Excretion of 17-ketosteroids, estrogens and gonadotropins before and after castration. J. Clin. Endocrinol., 1942, 2, 450.

25. Hamblen, E. C., Cuyler, W. K., and Baptist, M., Urinary excretion of 17 -ketosteroids in ovarian failure. IV. During the climacteric and after artificial menopause. J. Clin. Endocrinol., 1941, 1, 777.

26. Ross, R. A., Involutional phase of menstrual cycle (climacteric). Am. J. Obstet. and Gynec., 1943, 45, 497.

27. Frank, R. T., Salmon, U. J., and Friedman, R., Determination of the luteinizing and the follicle stimulating principles in castrate and menopause urine. Proc. Soc. Exper. Biol. and Med., 1935, 32, 1666.

28. Tepperman, J., Engel, F. L., and Long, C. N. H., A review of adrenal cortical hypertrophy. Endocrinology, 1943, 32, 373.

29. Ingle, D. J., Problems relating to the adrenal cortex. Endocrinology, 1942, 31, 419.

30. Martin, S. J., Effect of certain endocrine secretions on the X-zone of the adrenal cortex of the mouse. Proc. Soc. Exper. Biol. and Med., 1930, 28, 41.

31. a. Poll, H., Ǔber die Einwirkung von Proviron auf die männliche Nebenniererinde. Anat. Anz., 1933, 77, 113.

b. Poll, H., Sexualhormon und Nebenniere. Deutsche med. Wchnschr., 1933, 59, 567.

32. McEuen, C. S., Selye, H., and Collip, J. B., Effect of testosterone on somatic growth. Proc. Soc. Exper. Biol. and Med., 1937, 36, 390.

33. Korenchevsky, V., Dennison, M., and Hall, K., Action of testosterone propionate on normal adult female rats. Biochem. J., 1937, 31, 780.

34. Starkey, W. F., and Schmidt, E. C. H., Jr., Effect of testosterone propionate on $\mathrm{X}$-zone of mouse adrenal. Endocrinology, 1938, 23, 339.

35. Wolfe, J. M., and Hamilton, J. B., Action of testosterone propionate on the structure of the anterior pituitary of the female rat with particular reference to the effects of prolonged administration on the level of cells. Endocrinology, 1939, 25, 572.

36. Selye, H., Morphological changes in female mice receiving large doses of testosterone. J. Endocrinol., 1939, 1, 208.

37. Mazer, M., and Mazer, C., Effect of prolonged testosterone propionate administration on the immature and adult female rat. Endocrinology, 1939, 24, 175.

38. Selye, H., Interactions between various steroid hormones. Canad. M. A. J., 1940, 42, 113.

39. Selye, H., Effect of dosage on morphogenetic actions of testosterone. Proc. Soc. Exper. Biol. and Med., 1941, 46, 142.
40. Schilling, W., and Laqueur, G. L., Effect of the estrone cycle on the action of testosterone propionate on the organ and body weights of female rats. Endocrinology, 1942, 30, 753.

41. Clausen, H. J., The atrophy of the adrenal cortex following the administration of large doses of progesterone. Endocrinology, 1940, 27, 989.

42. Selye, H., and Friedman, S. M., Action of various steroid hormones on the testis. Endocrinology, 1941, 28, 129.

43. Selye, H., Collip, J. B., and Thomson, D. L., Effect of estrin on ovaries and adrenals. Proc. Soc. Exper. Biol. and Med., 1935, 32, 1377.

44. Burrows, $H$., Changes induced by oestrogens in adrenals of male mice. J. Path. and Bact., 1936, 43, 121.

45. Ellison, E. T., and Burch, J. D., Effects of estrogenic substances upon the pituitary, adrenals and ovaries. Endocrinology, 1936, 20, 746.

46. Tuchmann, $H$., Lesions of testicles after injection of estrogenic substances. Compt. rend. Soc. de biol., 1936, $122,1239$.

47. Lacassagne, A., and Raynaud, A., Action de l'oestrine sur la zone $\mathrm{X}$ et sur le cortex de la surranale chez la souris. Compt. rend. Soc. de biol., 1937, 124, 1186.

48. del Castillo, E. B., and Sammartino, C., Action of large and continued doses of estrone on the endocrine and sex organs of rats. Rev. Soc. Argent. de biol., 1937, 13, 455.

49. Loeser, A. A., and Erbacher, K., Pharmacology and toxicology of synthetic estrogens. Ztschr. f. d. ges. exper. Med., 1939, 105, 430.

50. Hashimoto, E. I., Effect of duration of postoperative interval on quantitative changes in adrenal glands of ovariectomized albino rats. Anat. Rec., 1940, 81, 205.

51. Ingle, D. J., Diabetogenic effect of stilbestrol in force-fed normal and partially depancreatized rats. Endocrinology, 1941, 29, 838.

52. Golla, Y. M. L., and Reiss, M., Observations on adrenocorticotropic action. J. Physiol., 1941, 100, $1 \mathrm{P}$.

53. Morrell, J. A., and Hart, G. W., Studies on stilbestrol. Some effects of continuous injections of stilbestrol in adult female rats. Endocrinology, 1941, 29, 796.

54. Morrell, J. A., and Hart, G. W., Studies on stilbestrol. Effect of massive doses on normal inmature female rats. Endocrinology, 1941, 29, 809.

55. Janes, R. G., and Nelson, W. O., The influence of diethylstilbestrol on the carbohydrate metabolism of normal and castrate rats. Am. J. Physiol., 1942, 136, 136.

56. Selye, H., and Albert, S., Age factor in responsiveness of pituitary and adrenals to folliculoids. Proc. Soc. Exper. Biol. and Med., 1942, 50, 159.

57. Albert, S., and Selye, H., Effect of various pharmacological agents on the morphogenetic actions of 
estradiol. J. Pharmacol. and Exper. Therap., 1942, 75, 308.

58. Albert, S., Influence of testosterone on the morphogenetic actions of estradiol. Endocrinology, 1942, 30, 454.

59. Breneman, W. R., Action of diethylstilbestrol in chick. Endocrinology, 1942, 31, 179.

60. Selye, H., and Collip, J. B., Fundamental factors in the interpretation of stimuli influencing endocrine glands. Endocrinology, 1936, 20, 667.

61. Wolfe, J. M., and Hamilton, J. B., Comparative action of testosterone compounds, of estrone, and of combinations of testosterone compounds and estrone on the anterior hypophysis. Endocrinology, 1937, 21, 603.

62. Pfeiffer, C. A., Alterations in the percentage of cell types in the hypophysis by gonad transplantation in the rat. Endocrinology, 1937, 21, 812.

63. Makepeace, A. W., Weinstein, G. L., and Friedman, M. H., Effect of progestin and progesterone on ovulation in the rabbit. Am. J. Physiol., 1937, 119, 512.

64. Dempsey, E. W., Follicular growth rate and ovulation after various experimental procedures in the guinea pig. Am. J. Physiol., 1937, 120, 126.

65. Laroche, G., Simonnet, H., and Bompard, E., Influence de la progésterone sur l'élimination urinaire des principes gonadotropes. Compt. rend. Soc. de biol., 1937, 126, 1159.

66. Astwood, E. B., and Fevold, H. L., Action of progesterone on gonadotropic activity. Am. J. Physiol., 1939, 127, 192.

67. Clauberg, C., Die Stimulierung der männlichen Geschlechtsdrüse durch weibliches Sexualhormon. (Tierexperimentelle Untersuchungen.) Zentralb. f. Gynäkol., 1936, 60, 1457.

68. Leonard, S. L., Changes in the relative amounts of follicle stimulating and luteinizing hormones in the hypophysis of the female rat under varying experimental conditions. Endocrinology, 1937, 21, 330.

69. Fevold, H. L., and Fiske, V. M., The inhibition of the action of the follicle stimulating hormone by the pituitary. Endocrinology, 1939, 24, 823.

70. Zalesky, M., Wells, L. J., Overholser, M. D., and Gomez, E. T., Effects of hypophysectomy and replacement therapy on the thyroid and adrenal glands of the male ground squirrel. Endocrinology, 1941, 28, 521.

71. de Boissezon, P., and Peyrot, M., Experimental variations of the weight of the adrenal capsules and the cholesterol content of these organs in the guinea pig after injection of urine from pregnant women. Arch. Soc. Sci. Med. Montpellier, 1934, 15, 307.

72. Inohara, S., Einfluss des Schwangerenharns auf die Nebenniere. IV. Mitt. Die Veränderungen der Nebennierenrinde der verschiedenen Teire bei Schwangeren un Injektion des sogenannten $\mathrm{Hy}-$ pophysenvorderlappenhormons und eine Frage über Vakuolisierung in der Rinde. Mitt. jap. Ges. Gynäkol., 1935, 30, 20.
73. Savona, B., Ormoni preiporisari (urina dì gravida e prolan) e modificazioni della corteccia surrenale. Riv. ital. Ginec., 1935, 18, 286.

74. Esiaschwili, I. N., Der Einfluss des Sexualhormon auf Nebennierenrinde. Zentralbl. f. Gynäkol., 1935, 59, 2741.

75. de Boissezon, P., The adrenal cortex of the guinea pig and its modifications after injection of urine from pregnant women. Bull. d'histol. appliq. a la physiol., 1936, 13, 129.

76. Golla, Y. M. L., and Reiss, M., Corticotrophic activity in pregnant mares' serum. J. Endocrinol., 1942, 3, 5.

77. Smith, P. E., Severinghaus, A. E., and Leonard, S. L., The effect of castration upon the sex-stimulating potency and the structure of the anterior pituitary in rabbits. Anat. Rec., 1933, 57, 177.

78. Hellbaum, A. A., and Greep, R. O., Qualitative changes induced in gonadotropic complex of pituitary by testosterone propionate. Endocrinology, 1943, 32, 33.

79. Andersen, D. H., and Kennedy, H. S., The effect of gonadectomy on the adrenal, thyroid and pituitary glands. J. Physiol., 1933, 79, 1.

80. Winter, C. A., and Emery, F. E., Compensatory adrenal hypertrophy in the rat as influenced by sex, castration, time and thyroidectomy. Anat. Rec., 1936, 66, 401.

81. Lawless, J. J., Castration in rats with and without removal of epididymus. Anat. Rec., 1936, 66, 455.

82. Korenchevsky, K., Dennison, M., and Eldridge, M., Effects of $\Delta^{4}$-androstenedione and $\Delta^{5}$-androstenediol on castrated and ovariectomized rats. Biochem. J., 1937, 31, 467.

83. Hall, K., and Korenchevsky, K., Effects of castration and of sexual hormones on the adrenals of male rats. J. Physiol., 1938, 91, 365.

84. Zeckwer, I., The effect of combined thyroidectomy, and gonadectomy on compensatory adrenal hypertrophy in unilaterally adrenalectomized rats. Am. J. Physiol., 1938, 123, 266.

85. Zuckerman, S., Bourne, G., and Lewes, D., Cyclical changes in adrenal glands of spayed rats submitted to estrogen injections. Nature, 1938, 142, 754.

86. Chiodi, H., Action of prepubertal castration on the endocrine weights of albino rats. Rev. Soc. Argent. de Biol., 1938, 14, 246.

87. Howard, E., and Gengradom, S., The effects of ovariectomy and administration of progesterone on the adrenal X-zone and the uterus. Endocrinology, 1940, 26, 1048.

88. Bourne, G., and Zuckerman, S., Changes in the adrenals in relation to the normal and artificial threshold estrus cycle in the rat. J. Endocrinol., 1940, 2, 283.

89. Korenchevsky, K., Dennison, M., and Brovsin, I., The assay and the effect of testosterone on rats compared with those of other sexual hormones. Biochem. J., 1936, 30, 558. 
90. Deansley, R., and Parkes, A. S., Multiple activities of androgenic compounds. Quart. J. Exper. Physiol., 1937, 26, 393.

91. Haitai, S., The growth of organs in the albino rat as affected by gonadectomy. J. Exper. Zool., 1915, $18,1$.

92. Freudenberger, C. P., and Billeter, O. A., The effect of spaying on body growth and organ weights of the albino rat. Endocrinology, 1935, 19, 347.

93. Freudenberger, C. P., and Howard, P. M., Effects of ovariectomy on body growth and ovarian weights of the young albino rat. Proc. Soc. Exper. Biol. and Med., 1937, 36, 144.

94. Freudenberger, C. P., and Hashimoto, E. I., A summary of data for the effects of ovariectomy on body growth and organ weights of the young albino rat. Am. J. Anat., 1937, 62, 93.

95. Billeter, O. A., The effect of spaying and theelin injections on body growth and organ weights of the albino rat. Am. J. Anat., 1937, 60, 367.

96. Lauson, H., Heller, C. G., and Sevringhaus, E. L., Effects of graded doses of estrin upon the pituitary, adrenal, and thymus weights of mature ovariectomized rats. Endocrinology, 1937, 21, 735.

97. Blumenfeld, C. M., The effects of ovariectomy on the adrenal glands of the albino rat. Endocrinology, 1939, 24, 723.

98. Waterman, L., The influence of castration on adrenal weight in female rats. Acta brev. Neerland, 1939, 9, 263.

99. Astwood, E. B., and Tyslowitz, R., An assay method for corticotrophin. Fed. Proc., 1942, 1, 4.

100. Li, C. H., Simpson, M. E., and Evans, H. M., Isolation of adrenocorticotropic hormone from sheep pituitaries. Science, 1942, 96, 450.

101. Simpson, M. E., Evans, H. M., and Li, C. H., Bioassay of adrenocorticotropic hormone. Endocrinology, 1943, 33, 261.

102. Sayers, G., White, A., and Long, C. N. H., Preparation and properties of pituitary adrenotropic hormone. J. Biol. Chem., 1943, 149, 425.

103. Sayers, G., White, A., and Long, C. N. H., Preparation of pituitary adrenotropic hormone. Proc. Soc. Exper. Biol. and Med., 1943, 52, 199.

104. Ingle, D. J., Li, C. H., and Evans, H. M., The effect of pure adrenocorticotropic hormone on the work performance of hypophysectomized rats. Endocrinology, 1944, 35, 91.

105. Marx, W., Simpson, M. E., Li, C. H., and Evans, H. M., Antagonism of pituitary adrenocorticotropic hormone to growth hormone in hypophysectomized rats. Endocrinology, 1944, 33, 102.

106. a. Houssay, B. A., Biasotti, A., Mazzacco, P., and Sammartino, R., Action of extract of anterior hypophysis on the suprarenals. Compt. rend. Soc. de biol., 1933, 114, 737.

b. Houssay, B. A., Biasotti, A., Mazzacco, P., and Sammartino, R., The action of anterior hypophysis extract on the adrenals. Rev. Soc. Argent. de biol., 1933, 9, 262.
107. a. Collip, J. B., Anderson, E. M., and Thomson, D. L., Adrenotropic hormone of the anterior pituitary lobe. Lancet, 1933, 2, 347.

b. Collip, J. B., Selye, H., and Thomson, D. L., Beiträge zur Kenntinis der Physiologie des Gehirnanhanges. Virchows Arch. f. path. Anat., 1933, 290, 23.

108. Anselmino, K. J., Hoffman, F., and Herold, L., The adrenotropic action of anterior pituitary extracts. Klin. Wchnschr., 1933, 12, 1944.

109. Emery, F. E., and Atwell, W. J., Hypertrophy of adrenal glands following administration of pituitary extract. Anat. Rec., 1933, 58, 17.

110. Emery, F. E., and Winter, C. A., The adrenotropic substance of the hypophysis as influenced by age, castration, sex and thyroparathyroidectomy. Anat. Rec., 1934, 60, 381.

111. Atwell, W. J., Effect of thyreotropic and adrenotropic principles of hypophysectomized amphibia. Anat. Rec., 1935, 62, 361.

112. Moon, H. D., Preparation and biological assay of adrenocorticotropic hormones. Proc. Soc. Exper. Biol. and Med., 1937, 35, 649.

113. Reese, J. D., and Moon, H. D., The Golgi apparatus of the cells of the adrenal cortex after hypophysectomy and on the administration of adrenocorticotropic hormone. Anat. Rec., 1938, 70, 543.

114. Meyer, R. K., Mellish, C. H., and Kupperman, H. S., Gonadotropic and adrenotropic hormones of the chicken hypophysis. J. Pharmacol. and Exper. Therap., 1939, 65, 104.

115. Miller, R. A., and Riddle, O., Stimulation of adrenal cortex of pigeons by anterior pituitary hormones and by their secondary products. Proc. Soc. Exper. Biol. and Med., 1939, 41, 518.

116. Moon, H. D., Effect of adrenocorticotropic hormone in 4 day old rats. Proc. Soc. Exper. Biol. and Med., 1940, 43, 42.

117. Davidson, C. S., and Moon, H. D., Effect of adrenocorticotropic extract on accessory reproductive organs of castrated rats. Proc. Soc. Exper. Biol. and Med., 1936, 35, 281.

118. Davidson, C. S., Effect of adrenotropic extract upon the accessory reproductive organs of castrated rats. Proc. Soc. Exper. Biol. and Med., 1937, 36, 703.

119. Hodler, D., Surrénales et masculinization. Arch. d'anat., d'histol. et d'embryol., 1937, 24, 1.

120. Hisaw, F. L., Hertz, R., Hellbaum, A. A., and Fevold, H. L., Luteinization of ovary of sexually immature monkey. Proc. Soc. Exper. Biol. and Med., 1932, 30, 39.

121. Talbot, N. B., Personal communication.

122. Broster, L. R., Gardiner Hill, H., and Greenfield, J. G., The adrenogenital syndrome associated with cortical hyperplasia; the results of unilateral adrenalectomy. Brit. J. Surg., 1932, 19, 557.

123. Talbot, N. B., Butler, A. M., and Berman, R. A., Adrenal cortical hyperplasia with virilism: diagnosis, course and treatment. J. Clin. Invest., 1942, 21, 559. 